\title{
SOLICITOR'S NEGLIGENCE: A COMMENT ON DEYONG AND RAIBMON v. WEEKS
}

\author{
W.S. SCHLOSSER*
}

\begin{abstract}
The recent case of Deyong and Raibmon v. Weeks ${ }^{1}$ decides that a solicitor can be liable to his client in tort as well as contract. Although this conclusion is consonant with lower court decisions in England and other provincial jurisdictions in Canada, it is new to Alberta. If followed, it will rid the common law of an anomaly that has been with us for at least fifty years.
\end{abstract}

\section{THE DECISION}

Weeks, the solicitor, failed to carry out specific instructions given him by Deyong, his financier client. The transaction concerned an unsecured loan to finance a speculative investment. Weeks had been instructed to confirm that certain independent parties to a proposed agreement were ready and willing to perform their obligations before the money was loaned. On the strength of a telex, funds were advanced. But the telex was a fabrication by the person seeking the loan. The independent party knew nothing of the proposed agreement. The money was not recovered. Deyong sued Weeks for, inter alia, failing to get independent confirmation. Weeks was held to be liable to his client in tort for the negligent performance of his professional duties. Weeks was also liable to Raibmon, Deyong's silent partner, for negligence.

Along with confirming that a solicitor may be liable to third parties in tort and clarifying the obligations of a solicitor in commercial transactions ${ }^{2}$, the decision may have a profound ef fect upon the foundation of a solicitor's liability to his client. After reciting a number of cases which limit this to contract ${ }^{3}$ Chrumka J. said: ${ }^{4}$

In Midland Bank Trust Co. Ltd and anotherv. Hett Stubbs and Kemp (supra) Oliver J. did a very thorough and historical analysis of the cases dealing with solicitor's liability. There was a duty of care imposed upon the solicitors by reason of the solicitor-client relationship. The reasoning of His Lordship is very persuasive and accordingly in my view, Mr. Weeks is liable both in contract and in tort to Mr. Deyong.

Since the rules of remoteness in tort and contract appear to have merg$e^{5}$, finding tort to be an alternative foundation for liability may make no

- B.Sc. (Alberta), B.A. (King's College), M.A. (Dalhousie), B.A. (Hon. Juris. Oxon.) Articling with the firm of Duncan \& Craig in Edmonton. The author would like to acknowledge, with thanks, the helpful comments of David Percy and John M. Hope.

1. [1983] 43 A.R. 342 (Q.B.).

2. See, for example, J.E. Cote, “E \& O Bulletin \#12”, August 1983.

3. Supra n. 1 at 360 (para. 55): Groom v. Crocker [1939] 1 K.B. 94 (C.A.); Lake v. Bushby [1949] 2 All E.R. 964 (K.B.); Clark v. Kirby-Smith [1964] Ch. 506; See also n. 14.

4. Supran. 1 at 365 .

5. See, for example, H. Parsons (Livestock) Ltd. v. Uttley Ingham \& Co. (1977) 3 W.L.R. 990 (Q.B.); Anglia T.V.v. Reed [1972] I QB 60; Esso Petroleum Co. Ltd. v. Mardon [1976] 2 All E.R. 5 at 15 (C.A.) per Lord Denning M.R.; In Kienzle v. Stringer (1981) 21 R.P.R. 44 at 49 et seq. Zuber J.A. found the tests to be so imprecise as to be practically indistinguishable; In John Maryon International Ltd. v. New Brunswick Telephone Co. Ltd. (1982) 141 D.L.R. (3d) 193 at 226 (N.B.C.A.) La Forest J.A. suggests that which foundation one chooses rarely will make a difference; Contra, Asamera Oil Corp. Ltd. v. Sea Oil \& General Corp (1978) 89 D.L.R. (3d) 1 at 8 (S.C.C.) per Estey J.; and The Heron II [1969] I A.C. 30 per Lord Reid. 
practical difference to the outcome. ${ }^{6}$ In other words the actual award of damages may not be different. But if tort is another ground for a solicitor's liability to his client, there will be more occasions when solicitors are accountable for their clients' loss. If the client may now recover in tort, a new cause of action is open to him. This aspect of the decision merits some comment.

\section{HISTORICAL AND THEORETICAL FRAMEWORK}

Case, or to be more specific, the medieval writs of assumpsit for misfeasance ${ }^{7}$ provide the historical model for solicitor's negligence. The form of action is contractual and the allegation is breach of an obligation to use care. Here something is undertaken to be done (assumpsit), but it is done badly, resulting in injury. ${ }^{8}$ In these writs we find the lineage of tort in a contractual setting.

The earliest instances of such writs concern professionals, artificers and later, bailees. ${ }^{9}$ Although the common law was quick to find a duty outside the terms of the contract where the tortfeasor exercised a 'common calling', ${ }^{10}$ it would not do so for professionals. "The situation of the bailee or the innkeeper was distinguished from that of a solicitor.

Owing largely to the old forms of action and a reluctance to place solicitors in the same category as those under a public duty, the solicitor's obligations arose from the contract only and did not exist independently. This was not the case for the bailee. His duty arose from his status and the nature of his trade. As Prosser says, the fact of the bailee's possession, not the contract, created an obligation. ${ }^{12}$ The contractual duties

6. But see Jacks v. Davis [1983] I W.W.R. 327, (1982) 22 C.C.L.T. 266; aff'g (1980) 12 C.C.L.T. 298 (B.C.C.A.); In J. Irvine's annotation (Id. at 299) of the case at first instance he says:

... the first obvious point to be made is that the cause of action advanced by the Plaintiff was crucial to the measure of his recovery.

While the solution in the case was novel ('breach of fiduciary duty' prevailed over alleged negligence) decisions such as these are cause for lingering doubts. If the tests have in fact merged, questions of remoteness or apportionment should create no difficulties. The shorter limitation period for tort is inconsequential.

7. S.F.C. Milsom, Historical Foundations of the Common Law (2nd ed. 1981) 316-20, 400. 1 have condensed the history somewhat for the sake of brevity.

8. F.W. Maitland, The Forms of Action at Common Law (1968) 55. In the Appendix "Select Writs" at 73-74 we find an example of a Writ of Trespass on the case in assumpsit for misfeasance:

... the said $X$ undertook well and competently to cure the right eye of the said $A$, which was accidentally injured, for a certain sum of money beforehand received, he the same $X$ so negligently and carelessly applied his cure to the said eye that the said $A$ by the fault of him the said $X$ totally lost the sight of the said eye, to the damage of him the said $A$ of twenty pounds. ...

The form is instructive and the points for comparison are obvious.

9. Maitland, id. at 56.

10. See, for example, Turnerv. Stallibrass [1898] L.R. I QB 52, (1898) LJ vol 67 NS 52 (C.A.); W.L. Prosser, Handbook of the Law of Torts, (3rd ed. 1964) 637. Prosser suggests that: ... it [a common law duty] would exist if there were no contract at all and the goods were found on the highway.

11. But see Hedley Byrne \& Co. v. Heller \& Partners [1964] A.C. 465, [1963] 2 All E.R. 575, [1963] 3 W.L.R. 101, [1963] I Lloyd's Rep. 485.

12. Prosser, supra n. 10. 
were incidental to the duties generated by the kind of work done. Diplock L.J. (as he then was) in Bagot v. Stevens Scanlan \& Co. said:13

I accept that there may be cases where a similar duty is owed both under contract and independently of contract. I think that upon examination all those will turn out to be cases where the law in the old days recognized either something in the nature of a status like a public calling (such as common carrier, common innkeeper, or a bailor or bailee) or the status of master and servant. There it can be properly said, as it was in such cases as Lister v. Romford Ice \& Cold Storage Co., 1957 A.C. 555, 195712 All E.R. 125 (H.L.), that independently of contract, there existed from the mere status a relationship which gave rise to a duty of care not dependent upon the existence of a contract between the parties. But I do not think that that principle applies to professional relationships of the kind with which I am concerned here, where someone undertakes to exercise by contract his professional skill in relation to the matter. I think that the authorities are much too strong against that and are binding on me in the capacity in which I am sitting here today.

Thus despite tortious elements, the foundation of a solicitor's liability lay in contract alone. ${ }^{14}$ In a manner of speaking the courts focused their attention on the "nature of the wrong rather than the fault of the wrongdoer". ${ }^{15}$ Hence the solicitor was exempt from the concurrent liability suffered by such as the bailee. ${ }^{16}$ Even though he may have contracted to discharge some duty already imposed upon him by the law, ${ }^{17}$ the plaintiff's remedy lay solely in contract.

Not only were solicitors in an anomalous position when compared with those exercising a common calling, since Donoghue v. Stevenson ${ }^{18}$ and the emergence of a nominate (and "universal") tort of negligence, they

13. [1966] I Q.B. 197, [1964] 3 All E.R. 577. In this case the limitation period for contract not tort - applied to architects for alleged negligence in the performance of their professional duties.

14. Davies v. Lock (1844) 3 L.T.O.S. 125; Bean v. Wade (1885) T.L.R. 157; Groom v. Crocker, supra n. 3; Lake v. Bushby, supra n. 3; Hallv. Meyrick [1957] 2 Q.B. 455; Clarke v. Kirby-Smith, supra n. 3; Winrob v. Street (1959) 19 D.L.R. (2d) 172 at 174 (B.C.S.C.) per Wilson J.; Panamaroff v. Reid (1962) 32 D.L.R. (2d) 126 at 129 (B.C.S.C.) per Verchere J.; Schwebel v. Telekes (1967) 61 D.L.R. (2d) 470 (Ont. C.A.) per Laskin J.A. (as he then was): concerning notaries public; Rowswellv. Pettit (1968) 68 D.L.R. (2d) 202, [1968] 2 O.R. 81 (Ont. H.C.), the amount of damages was reconsidered in [1969] 1 O.R. (2d) 22 (Ont. C.A.); aff'd subnom Wilson v. Rowswell (1970) 11 D.L.R. (3d) 737 (S.C.C.) both Courts were, however, silent on the question of principle; Banks v. Reid [1977] 4 C.C.L.T. 1 (Ont. C.A.); rev'g in part (1974) 53 D.L.R. (3d) 27; Gouzenko v. Harris [1976] I C.C.L.T. 37 at 56 (Ont. H.C.); Dominion Chain Co. Lid. v. Eastern Construction Co. Ltd. (1976) 68 D.L.R. (3d) 385 (Ont. C.A.) per Wilson J.A., dissenting, (architects and engineers); Royal Bank of Canada v. Clarke (1978) 88 D.L.R. (3d) 76 (N.B.S.C.A.D.) per Hughes C.J.; aff'g (1977) 18 N.B.R. (2d) 643; Messineo v. Beale (1978) 86 D.L.R. (3d) 713 (Ont. C.A.); aff'g 71 D.L.R. (3d) 31; Page v. Bick (1980) 12 C.C.L.T. 43 (Ont. S.C.) (some doubts were expressed in both Messineo and Page, however); MacDonald Construction Co. Ltd. v. Ross (1980) 32 Nfld. \& P.E.I.R. 450 at 453 (P.E.I.S.C.); Spence v. Bell (1982) 39 A.R. 239 (Alta. C.A.) per Haddad J.A. (Harradence J.A. concurring); Andrei v. McKillop (1982) 38 O.R. (2d) 21 (Co. Ct.) per McCart J; Rhude v. Corbett (1981) 47 N.S.R. (2d) 472 (S.C.T.D.) per Burchell J. (obiter); Bjorninen v. Mercredi [1983] 4 W.W.R. 633 at 640 (Man. Q.B.); see also Cordery on Solicitors (6th ed., Graham-Green ed., 1968) 187-88. The Canadian starting point is almost invariably Schwebel.

15. Milsom, supra $\mathrm{n} .7$ at $\mathbf{3 9 9}$ speaking of the lineage of the nominate tort of negligence.

16. See Salmond on Torts, (12th ed., 1957) 10.

17. Given this is possible in principle.

18. M'Alister (Donoghue) v. Stevenson [1932] A.C. 562. See also Anns v. Merton [1979] A.C. 728, [1977] 2 All E.R. 492. 
were in an anomalous position as regards the common man. ${ }^{19}$ Indeed the solicitor became an anomaly in the general law of negligence; both his professional status and the contract of retainer prevented a remedy for simple common law negligence. No duty to one's client existed, or was actionable, outside the contract.

Several effects of this reasoning are in evidence. First, alternative remedies in tort were precluded. Second, damages were awarded on contract principles and finally, until Hedley Byrne, ${ }^{20}$ third party remedies were excluded by the doctrine of privity. Solicitor's liability was limited by a dated historical and theoretical framework.

\section{DEYONG AND RAIBMONv. WEEKS: \\ THE GENERAL PRINCIPLE OF CONCURRENT LIABILITY AND SOLICITOR'S NEGLIGENCE}

Now fault appears to be paramount. But the matter is far from being settled. It is clear that solicitors can be liable to third parties - as Weeks was to Raibmon - for negligence in the performance of their professional duties. ${ }^{21}$ Deyong is an example of the general trend in lower courts toward finding a duty owed by solicitors to their clients alongside of the contract of retainer. ${ }^{22}$ Although recent Canadian decisions which support this proposition apparently were not at bar in Deyong, and the outcome of the case might have been the same without invoking the alternate ground, Deyong is consistent with this trend.

Such decisions, however, bring solicitors squarely into the borderland of tort and contract. In this desolate area the law is in a most unsatisfactory state. Despite inclinations of lower courts, several decisions of the Supreme Court of Canada disclose an unwillingness to accept concurrent liability. In J. Nunes Diamonds Ltd. v. Dom. Elec. Protections Co., ${ }^{23}$ Pigeon J. says: ${ }^{24}$

19. It should be noted that along with common callings there existed concurrent liability as between master and servant: Govett v. Radnidge (1802) 102 E.R. 520; Brown v. Boorman (1844) 11 Cl. \& Fin.1, R.R. vol. LXV I (H.L.); aff'g [1842] 3 Q.B. 511; (cf. however, Jarvis v. Moy [1936] 1 K.B. 399 per Slesser L.J. (C.A.)); Lister v. Romford Ice \& Cold Storage Co. [1957] A.C. 555, [1957] 1 All E.R. 125 and Dominion Chain Co. Ltd. v. Eastern Construction Co. Ltd., supra n. 14 per Jessup J.A. at 392 et seq.

20. Supra n. 11. For the consequences see, for example: Wittingham v. Crease \& Co. (1978) 88 D.L.R. (3d) 353 (B.C.S.C.) per Atkins J.; Ross v. Caunters [1979] 3 All E.R. 580 (Ch. D.) per Megarry V.C.. See also Tracy \& Morin v. Atkins (1979) 16 B.C.L.R. 223 (B.C.C.A.) per Memetz C.J.B.C.; Barman's Beauty Supplies Ltd. v. Kempster (1974) 4 O.R. 626 (Co. Ct.), and Deyong supra n. 1.

21. Id.

22. The suggestion was made as early as 1914. See Nocton v. Lord Ashburton [1914] A.C. 332 at 956, [1914-15] All E.R. Rep. 45 at 54 per Viscount Haldane L.C.; Messineo v. Beale, supra n. 14 per Zuber J.A. (Ont. C.A.) dissenting in part; Kienzle v. Stinger, supra n. 5; Power v. Halley (1978) 88 D.L.R. (3d) 381 (Nfld. S.C.T.D.) per Mifflin C.J.T.D.; Jacobson Ford-Mercury Sales Lid. v. Sivertz [1980] 1 W.W.R. 141 (B.C.S.C.) per KirkeSmith J.; Midland Bank Trust Co. Ltd. v. Hett, Stubbs and Kemp [1978] 3 All E.R. 571, [1979] Ch. 384; McCormack and Zateman Limited v. McKelvey (1982) 33 N.B.R. (2d) 399 (Q.B.) per Barry J. (obiter); Baldwin v. Chalker and Pippy (1982) 39 Nfld. \& P.E.I.R. 18 perSteele J. (S.C.T.D.); Spencev. Bell, supra n. 14 per Kerans J.A. (dissenting).

23. [1972] S.C.R. 769, (1972) 26 D.L.R. (3d) 699.

24. Id. at 777-778. The remarks are based on dicta in Elder Dempster \& Co. Ltd. v. Paterson, Zochonis \& Co. Ltd. [1924] All E.R. Rep. 135, [1924] A.C. 522 (H.L.). 
... the basis of tort liability considered in Hedley Byrne is inapplicable to any case where the relationship between the parties is governed by a contract, unless the negligence relied on can properly be considered 'an independent tort' unconnected with the performance of that contract....

These remarks, possibly obiter, were quoted with approval by Ritchie $\mathrm{J}$. in Rivtow Marine Ltd. v. Washington Iron Works ${ }^{25}$ and reiterated by Pigeon J. in his dissenting opinion in Smith v. McInnis. There he said: ${ }^{26}$

... a breach of duty may constitute a tort only if it is a breach of duty owed independently of any contract with the claimant.

and further: 27

In the case of a solicitor retained to give advice, his duty to advise properly arises only under contract and I do not see how liability can arise other than on a contractual basis.

These remarks can be read in two ways: ${ }^{28}$ broadly, to mean that the existence of a contract precludes a remedy in tort for any areas governed by the agreement and; narrowly, to mean liability in tort is possible providing it is not excluded by the terms of the contract. ${ }^{29}$ On the broad reading, the bargain, not the common law determines the respective duties of the parties. Where there is a contract, there cannot be an actionable tort unless it is entirely unconnected with the performance of the contract. Strict concurrent liability in tort and contract is impossible. On the narrow reading, however, if the contract does not contain an exclusionary clause which addresses the duty in issue, breach of that duty may either be regarded as a breach of contract or a tort. Nothing but an exclusionary clause prevents a finding of concurrent liability.

Apart from these two readings, there have been numerous attempts to qualify or distinguish Pigeon J.'s remarks. First, they have been regarded as merely obiter and not binding. ${ }^{30}$ Second, Prowse J.A. (Harradence J.A. concurring) in Canadian Western Natural Gas Company Limited v.

25. [1974] S.C.R. 1189, [1973] 6 W.W.R. 692, (1973) 40 D.L.R. (3d) 530.

26. (1978) 91 D.L.R. (3d) 190 (S.C.C.).

27. Id. at 204.

28. As David Percy has pointed out.

29. Some instances of decisions which appear to endorse the broad reading are: Vardog Construction Company Ltd. v. Coulthard \& Associates Engineering Ltd. (1980) 36 A.R. 187 (Q.B.) per Agrios J.; Green Elm Holdings Ltd. v. J.H. Hogg \& Assoc. Ltd. (1982) 23 Alta. L.R. (2d) 177 (Q.B.); Kanetmatsu-Gosho (Canada) Inc. v. Sinclair Supplies Ltd. (1982) 16 B.L.R. 89 (Alta. Q.B. Chambers) per Funduk M.; Hansen v. Twin City Construction Co. Ltd. [1982] 4 W.W.R. 261 (Alta. Q.B.) per Feehan J.; International Racquetime Ltd. v. McDonald and Sport-Court Systems Ltd. (1981) 30 A.R. 456 (Q.B.) per Funduk M.; Medjuck and Budovitch Lid. v. A.D.I. Limited (1980) 33 N.B.R. (2d) 271 (T.D.); Horseshoe Creek Farms Ltd. v. Sterling Structures Co. Ltd. (No. 2) (1982) 15 Sask. R. 57 (C.A.); Kerr v. Gingras (1980) 24 B.C.L.R. 372 (S.C.); Sealand of the Pacific v. Robert McHaffie Ltd. (1974) 51 D.L.R. (3d) 702 (B.C.C.A.); Cominco Ltd. v. Westinghouse Canada Ltd. (1981) 127 D.L.R. (3d) 544 (B.C.S.C.); Nelson Lumber Company Ltd. v. Koch [1980] 4 W.W.R. (Sask. C.A.). Examples of cases which appear to endorse the narrow reading are: McNeilv. Village Locksmith Ltd. (1981) 129 D.L.R. (3d) 543 (Ont. H.C.); Surrey v. Carroll-Hutch and Associates Ltd. [1979] 6 W.W.R. 280 (B.C.C.A.) per Hinkson J.A.; John Maryon International Ltd. v. New Brunswick Telephone Co. Ltd., supra n. 5. The lists are not exhaustive.

30. Eg. Nelson Lumber, id. 
Pathfinder Surveys Ltd. ${ }^{31}$ has suggested that the independent duty is founded on the principle of Donoghuev. Stevenson. ${ }^{32}$ He says: ${ }^{33}$

The Esso case and the statement of Lord Wilberforce in the Anns case demonstrate the extension by the courts of common law duty of care set out in Donoghuev. Stevenson. We have the courts recognizing that such duty is not dependent upon contract, although its consequences may be so limited, but is an independent duty imposed by law in circumstances where there is a sufficient relationship of 'proximity and neighbourhood' between the wrongdoer and the person suffering damages.

With respect, if this reasoning prevails, the effect of Pigeon J.'s opinion has been considerably diminished. It amounts to saying that there might be concurrent liability wherever there is negligence.

Similarily, the 'failure to warn' has been regarded as an independent tort ${ }^{34}$ which satisfies the requirement established in Nunes. Yet other cases have decided that the principles set forth by Pigeon $J$. do not apply to representations made, or acts occuring, before the formation of the contract, ${ }^{35}$ or where the person is in the business of giving information. ${ }^{36}$ Some courts, moreover, have avoided these difficulties by basing liability upon 'breach of fiduciary duty' and skirting the tort-contract borderland altogether. ${ }^{37}$

Chrumka J. in Deyong came to his decision about concurrent liability on the basis of Midland Bank, ${ }^{38}$ a case that found the extension of common law negligence to solicitors warranted on the principle of Hedley Byrne. ${ }^{39}$ As it stands, this brings the decision into direct conflict with the broad reading of Pigeon J.'s remarks in Nunes. ${ }^{40}$ But it must be remembered that Weeks breached the specific instructions given to him by Deyong. Whether tort or contract founded liability, it is respectfully submitted that the outcome would be the same. Furthermore, there is nothing in the actual award of damages which compels saying 'this is clearly a contract case' or 'this is clearly a tort case'. Thus, if a broad reading of Pigeon J.'s remarks is correct, the conflict is only with the alternative ground, tort.

31. (1980) 12 Alta. L.R. (2d) 135, 12 C.C.L.T. 211 (C.A.). The decision is greatly influenced by Esso Petroleum Co. v. Mardon, supra n. 5. The Pathfinder case held that the barrier brought down by Esso was not limited to actions against professionals, and alternative remedies in tort or contract might be universally available. See also Batty v. Metropolitan Property Realisations [1978] QB 544, [1978] 2 All E.R. 445 (C.A.) on the general point.

32. Supran. 18.

33. Supra n. 31 at 145 (emphasis added). The report at (1980) 12 C.C.L.T. at 231-2 is even stronger.

34. Cominco, supra n. 29; see also McNeil, supra n. 29; failure to warn one's client was regarded as an actionable breach in Majorv. Buchanan (1975) 61 D.L.R. (3d) 46 (Ont. H.C.); see also Lake v. Bushby, supra n. 14.

35. Eg. Nelson Lumber, supra n. 29. See also Herrington v. Kenco Mortgage \& Investments Lld. (1981) 29 B.C.L.R. 54 per Paris J. (obiter).

36. And the misrepresentation leads to contract. Herrington, Id. at 62.

37. Jacks v. Davis, supra n. 6; Lapierre v. Young (1980) 117 D.L.R. (3d) 643 at 648 (Ont. H.C.) per Montgomery J..

38. Supra n. 22. It is submitted that Midland Bank is consistent with the narrow reading of Pigeon J.'s remarks.

39. Supran. 11.

40. Supran. 23. 
The number of courts willing to accept concurrent liability is increasing. Deyong is an example of this trend. But it is difficult to make general statements about this area of the law. The battle over the border is not yet won. Nevertheless, some observations can be made.

The bulk of decisions on the general principle support the broad reading of Pigeon J.'s remarks in Nunes. ${ }^{41}$ But that is not the end of the matter. A narrow reading has found acceptance on several occasions. ${ }^{42}$ Although relatively fewer cases have endorsed this interpretation, it cannot be ignored. The possibility of broad and narrow interpretations leaves open the question whether the fact of the contract or the existence of an exclusion clause will limit causes of action.

Second, there is a specific trend in lower courts to find solicitors liable in tort for negligence. ${ }^{43}$ This reasoning has applied both when the plaintiff is a client or a third party. The trend is supportable on the narrow reading of Pigeon J.'s remarks in Nunes and on the basis of a number of persuasive English decisions. The existence of this trend and the acceptance of a narrow reading simply adds uncertainty to matter of principle.

Finally, with respect, the weight of Pigeon J.'s remarks has been undermined by decisions which limit or distinguish them. Not only is there doubt about which interpretation should prevail, the remarks may be so eroded as to have lost their persuasive force altogether.

Thus it is difficult to state with confidence which way the balance has tipped. At best, uncertainty prevails and in this uncertainty there is cause for alarm. No firm answer on the state of tort and contract damages has appeared. Although the tests for remoteness may have merged, which ground is chosen might still make a difference to the outcome. Professionals must know whether contract or the common law founds their duties.$^{44}$ Solicitors, amongst others, must be able to conduct their affairs with certainty. They must know whether they can rely upon the agreement with their client.

\section{CONCLUSIONS}

Although it would be refreshing to see an anomalous situation removed from the law, it is the writer's opinion that there is good reason to preserve the old distinctions..$^{45}$ If they are not preserved, policy ${ }^{46}$ may bring the matter full circle.

Formerly, the courts would determine the scope of the retainer ${ }^{47}$ and proceed to decide whether the obligations imposed by it had been discharged. In this latter step, a standard of performance is applied to the

41. Seen. 29.

42. Seen. 29.

43. Seen. 22 and alson. 20.

44. On one hand there is "my solicitor", a term found to be hopelessly broad, insofar as duties were concerned, by Oliver J. in Midland Bank, supra n. 22 at 583 (see also Deyong at 361). On the other hand, there is strict construction of the retainer. Owing to the state of the law it remains for policy to strike a balance.

45. Cf. B. Morgan, "The Negligent Contract Breaker" (1980) Can. Bar. Rev. 299. Morgan argues that concurrent liability is to be preferred.

46. That is, the second step in the two stage test in Anns v. Merton, supran. 18.

47. See, for example, Spencev. Bell, supran. 14. 
facts. ${ }^{48}$ The standard resembled a test for negligence in a tort action. But under the old law the retainer determines the duties. The solicitor, having made an agreement, could be aware of his duties in advance and could govern his conduct accordingly. The courts were reluctant to re-write the bargain.

In light of the relative certainty arising from this arrangement, a shift in theory does not offer any solace to solicitors. If the trend continues unabated and the principles found in the broad reading of Pigeon J.'s opinion have been undermined, new duties will be imposed. Instead of asking how the obligations set by the retainer should be discharged, the courts may find themselves asking (and determining) what should have been done.

Not only would this introduce a new element of uncertainty into the conduct of a solicitor's affairs, he may not be able to offer his client economy in the most routine job. Even if the client has weighed the risk of having his solicitor do as little as possible and prefers to accept that risk, if the solicitor's obligations are not determined by the bargain the client may not choose economy. If it is not open to him to say "do as I ask, no more no less" 49 his directions become empty because he does not have to bear the risk.

If, on the other hand, the narrow reading prevails, a new burden is imposed on the solicitor as defendant. He must demonstrate that the specific instructions of his client are inconsistent with liability. But since solicitors have never incorporated exclusion clauses in their retainers and may be prevented from doing so by ethical considerations, ${ }^{50}$ the terms of the contract may be of limited assistance. In other words, a defence upon the contract may be lost.

The problems associated with this new burden, the necessity of certainty and the possibility of economy weigh strongly in favour of preserving the limits set by the retainer. If the old law can no longer do this, policy must. It is submitted that adding a new cause of action will not af fect the outcome of most decisions. Little may be accomplished by a shift in

48. The standard is discussed in Aaroe v. Seymour (1956) 6 D.L.R. (2d) 100 at 101-2 (Ont. H. C.) per Le bel J., cited with approval in Brennerv. Gregory(1972) 30 D.L.R. (3d) 672 (Ont. H.C.) per Grant J. and Pagev. Dick, supra n. 14. The obligations of an "ordinarily competent solicitor" are set out by Riley J. in Millican v. Tiffin Holdings Ltd. (at first instance) (1967) 60 D.L.R. (2d) 469 (S.C.C.); revg (1964) 49 D.L.R. (2d) 216, 50 W.W.R. 673. The remarks of Riley J. in Millican were cited with approval by Bowen J. in Schloss v. Koehler (1977) 4 Alta. L.R. (2d) 85 at 90 (S.C.T.D.). For an excellent and practical discussion generally see J.E. Cote, Professional Liability of Lawyers, Legal Education Society of Alberta 1980.

49. See Meadwell Enterprises Ltd. v. Clay and Company [1983] 3 W.W.R. 742 at 749 (B.C.S.C.). Lock J. excusing the third party solicitor from liability said:

He did what he was retained for, no more, no less.

While it may be difficult to prove that the solicitor has been engaged to perform a lesser standard, it should at least be possible in principle.

Note G.F. Scott, "Recent Developments in the Professional Liability of Lawyers" (1980) Legal Education Society of Alberta 4. The paper has been of general assistance in the preparation of this case comment.

50. An exclusion clause in a solicitor's retainer may well give rise to an immediate conflict of interest. 
theory. In light of this, if the old distinctions are lost, policy may bring the matter back to the point of departure.

The application of common law negligence to solicitors makes professional liability a grisly business. Judicial guidance on this topic and on the question of principle has become vital. Theoretical purity must not jeopardize one of the world's oldest professions. It is hoped that the recent alignment of solicitors with the common man in such decisions as Deyong will not have the unwanted consequence of providing a catch-all remedy for victims who also happen to be clients. 